\title{
Chemical Oxygen Demand Reduction using Lactic-acid Forming Bacteria to Treat River Mouth Sediment
}

\author{
HIROSHI OKUHATA ${ }^{1}$, HITOSHI MIYASAKA ${ }^{1}$, TAKEFUMI MIURA², \\ HIROYO MORIKAWA ${ }^{3}$, and KEN SASAKI ${ }^{2 *}$ \\ ${ }^{1}$ Kansai Electric Co., Environmental Research Center \\ / Keihanna-Plaza, 1-7, Seikacho, Sourakugun, Kyoto, 619-0237 \\ ${ }^{2}$ Graduate School of Engineering, Hiroshima Kokusai Gakuin University \\ / 6-20-1, Nakano, Akiku, Hiroshima, 739-0321, Japan \\ ${ }^{3}$ Meisui-Bio Research Institute, Hiroshima Kokusai Gakuin University \\ / 6-20-1, Nakano, Akiku, Hiroshima, 739-0321, Japan
}

\begin{abstract}
Six kinds of lactic-acid forming bacteria were isolated from an environmental preservation material (Ehime AI) and fermented and matured sediment mud from Osaka Bay. Among these isolated bacteria, strain Ob from Osaka Bay showed the highest COD removal of sediment mud (30.4\% reduction) after 4 weeks. Strain Aa from Ehime AI showed $13.8 \%$ COD removal as the highest active strain of lactic acid formation. High lactic-acid forming ability of bacteria was not correlated to high COD reduction. Strain Ob was identified as Paenibacillus motobuensis using genetic analysis.
\end{abstract}

Key words: sediment mud, purification, lactic acid bacteria, matured sediment mud, Ehime AI

\section{INTRODUCTION}

Large amounts of sediment mud accumulate in many places throughout the tidal flats of Hiroshima Bay and the Seno River mouth of the Kaita Bay ${ }^{1,2)}$. Hiroshima Bay has many oyster farms with accumulated sediment mud on the sea bottoms ${ }^{2}$. The sediment mud includes remnants from domestic sewage wastewater from rivers, along with oyster excretions and feces. The sediment mud releases hydrogen sulfide, phosphates, and nitrogenous compounds that spread throughout Hiroshima Bay causing blue tides (masses of low-oxygen sea water) and red tides (unusual phytoplankton growth). Both severely damage fish, shellfish and benthic animals on the sea bottom and the overall ecosystem of the tidal flats ${ }^{3)}$. Purification of the sediment mud on tidal flats remains a crucial task to improve the Hiroshima Bay coastal environment.

Many reports have described methods and ideas for improving and purifying sediment mud, including dredgeing ${ }^{3)}$, coal ash with aeration treatment ${ }^{4)}$, ozone treatment ${ }^{5)}$, benthic animal purification ${ }^{6}$, and lime powder sprinkling ${ }^{7)}$.However, such ideas have not been widely applied because of the costs and the purification capabilities of sediment mud in the field. Recently, the sprinkling of magnesium hydroxide ${ }^{8}$, converter slag ${ }^{9)}$, and granulated coal $\mathrm{ash}^{4)}$ on tidal flats and sea bottoms has been reported to suppress hydrogen sulfide, nitrogenous compounds, and the release of phosphates. These technologies are especially attractive because hydrogen sulfide suppression particularly improved the coastal sea and tidal flat environments $^{4,9)}$. In addition, these technol-

*Corresponding author 
ogies are attractive because they recycle waste materials. However, based on environmental preservation regulations, even though these artificial waste materials release only a small amount of borate, fluorine and cyanide, the coastal environments can be damaged. The practical purification of sediment mud remains difficult.

We have studied sediment mud purification using biotechnology with photosynthetic bacteria ${ }^{10)}$. Biotechnological remediation of sediment mud generally entails lower cost and environmentally friendly technologies. Some sediment mud from tidal flats in the Osaka Bay was fermented by itself and matured over 6-12 month periods. Finally the mud returned to sand. This process is apparently a function of lactic acid fermentation because similar effects were also observed by sprinkling environmental preservation materials (Ehime AI) mainly consisting of lactic-acid forming bacteria ${ }^{11}$.

This report describes our investigation of the contribution of lactic-acid forming bacteria to sediment mud purification. First, the lactic-acid forming bacteria were isolated from Ehime AI and the sediment mud obtained from the tidal flats of Osaka Bay. Using the isolated bacteria, we conducted chemical oxygen demand (COD) removal of sediment mud and lactic acid fermentation in laboratory experiments. Based on those data, we assessed the role of lactic-acid forming bacteria in sediment mud purification.

\section{MATERIALS AND METHOD}

Experimental materials As the source of the lactic-acid forming bacteria, we used a matured sediment mud consortium harvested from tidal flats in Osaka Bay and Ehime AI, which was purchased as an environmental preservation material from the Industrial Institute of Technology, Ehime Prefecture ${ }^{11)}$. The matured sediment mud consortium was prepared as follows: $2 l$ of sediment mud from the Osaka Bay was put in a $3 l$ bottle to which $20 \%(\mathrm{v} / \mathrm{v})$ of fresh sediment mud was added from the mouth of the Seno River, Hiroshima. Both mud contained a large amount of organic matters (COD of about 15 $\mathrm{mg} / \mathrm{g}$ dry mud). To enhance fermentation, a vitamin mixture of vitamin B1, nicotinic acid, and biotin (1, 1, and $0.01 \mathrm{mg} / \mathrm{l}$ sediment mud, respectively) ${ }^{10)}$ was added and mixed well. After one month of fermentation and maturation at $30{ }^{\circ} \mathrm{C}$ under static conditions, we removed about $20 \%$ (v/v) of fermented mud and about $20 \%$ fresh sediment mud from the Seno River mouth was added. The vitamin mixture was added. It was fermented continuously for one month. By repeating this process for one year, we prepared a matured sediment mud consortium of bacteria that was used for the source of the lactic-acid forming bacteria. The harvested sediment mud was highly polluted by organic matter from wastewater from food-processing factories and sewage wastewater discharged over a long period. The mud had accumulated on the tidal flats with a thick layer of sediment mud around the Seno River mouth.

As the source of lactic-acid forming bacteria, $1 \mathrm{ml}$ of Ehime AI liquid was also used. Ehime AI consists of lactic-acid forming bacteria, Bacillus sp. from natto, fermented soybean, and dry yeast for making bread ${ }^{11}$.

Isolation of lactic-acid forming bacteria About one gram of matured sediment mud consortium was suspended in a $100-\mathrm{m} l$ sterilized saline solution $(0.9 \% \mathrm{NaCl})$. One needle of this solution was scattered on a $\mathrm{BCP}$ agar plate and cultivated for one day at $30{ }^{\circ} \mathrm{C}$. The colonies showing yellow halos indicated acid production. High-growing colonies with yellow halos were selected and scattered again on another BCP agar plate and cultivated at $30{ }^{\circ} \mathrm{C}$ for one day. By repeating this procedure more than 10 times, three morphologically different strains were obtained, which showed high growth rates. The following was the BCP medium composition $(\mathrm{g} / \mathrm{l})$ : glucose 1.0 , yeast extract 2.5 , peptone 5.0 , polysorbate 80 (Tween 80 ) 1.0, l-cysteine 0.1 , bromocresol purple 0.06 and agar 15.0.

For isolation of the strains from Ehime AI, one needle of diluted Ehime AI solution $(1 \mathrm{ml}$ of Ehime AI liquid plus $99-\mathrm{m} l$ sterilized saline solution) was scattered on $\mathrm{BCP}$ agar plate and cultivated for one day at $30{ }^{\circ} \mathrm{C}$. The colonies showing yellow halos and high growth were cultivated on $\mathrm{BCP}$ plate more than 10 times as the same procedure as described before. Three morphologically 
different strains were obtained.

Cultivation of lactic-acid forming bacteria We put $50 \mathrm{~m} l$ of the sterilized BCP liquid medium (without agar and bromocresol purple) in a large test tube and inoculated one needle of the colony from the isolated bacteria on a plate. We cultivated this for three days under static conditions. Then the growth and lactic acid formations were investigated at $30{ }^{\circ} \mathrm{C}$.

For preparation of the concentrated seed solution, $200 \mathrm{~m} l$ of BCP liquid medium was cultivated in a $300-\mathrm{m} l$ conical flask for three days at $30{ }^{\circ} \mathrm{C}$ after one needle inoculation of each colony. Centrifugation $(10,000 \times \mathrm{x}, 20$ min) was conducted, and the seed solution was suspended in a sterilized saline solution. The bacteria concentration in seed suspension was adjusted to about $\mathrm{OD}_{660}=5$.

Purification experiment of sediment mud Using the seed suspension of the isolated lactic-acid forming bacteria, we conducted an indoor experiment of sediment mud purification. In a $2 l$ bottle, $1 l$ of sediment mud harvested from the Seno River mouth was put and $10 \mathrm{ml}$ of seed suspension $\left(\mathrm{OD}_{660}=5\right)$ were mixed well. This sediment mud was fermented for one month at $30{ }^{\circ} \mathrm{C}$. This mud was mixed at 2-3 day intervals until it became homogenous. When the mixed seed suspension was added, a total of $60 \mathrm{ml}$ of seed suspensions $(10 \mathrm{ml}$ of each seed suspension of six kinds of bacteria from Osaka Bay and Ehime AI) was added.

Genetic analyses of isolated lactic-acid forming bacteria A strain with high COD reduction from Osaka tidal flats and a rapidly growing bacteria from the Ehime AI were identified genetically. DNA extraction was conducted using Insta Gene Matrix (Bio-Rad Laboratories Inc., USA). For cycle sequencing, we used a BigDye Terminator v3.1 Cycle Sequencing Kit (Applied Biosystems, CA, USA). Analyses were conducted using Aporon 2.0 and Aporon DB-BA 6.0 (Techno Suruga Laboratory Co. LTD, Shizuoka, Japan).

Analysis COD was measured using a sulfuric acid method with a $1 / 40 \mathrm{~N} \mathrm{KMnO}$ solution. About $5 \mathrm{~g}$ of sample sediment mud (measured exactly as $5.053 \mathrm{~g}$, for example) was suspended in $100 \mathrm{~m} l$ of deionized water. Then the COD was measured after dilution.
This suspension was also filtrated with filter paper $(70 \mathrm{~mm}$ diameter and $0.2 \mathrm{~mm}$ thickness, Advantec No. 1; Advantec Toyo Kaisha Ltd., Tokyo, Japan) three times for lactic acid measurements. Lactic acid was measured by an F Kit (Boeringrer Mannhaim Biochemistry). Dry solids of sediment mud were measured using about $5 \mathrm{~g}$ of sediment mud, dried for $24 \mathrm{~h}$ at $105{ }^{\circ} \mathrm{C}$, and cooled in a desiccator. Microscopic observation $(\times 600)$ of the fermented and purified sediment mud was conducted using a suspension from which about $1 \mathrm{~g}$ of sediment mud was suspended in sterilized saline water.

\section{RESULTS AND DISCUSSION}

Isolation of lactic-acid forming bacteria and fermentation profile Three morphologically distinct strains from Ehime AI were isolated with high growth rates and high acid formation on an agar plate. The strain Aa was about $20 \mu \mathrm{m}$ in length, $1 \mu \mathrm{m}$ in width, and had a bent moiety resembling the letter "v" in one part of the cell. The strain Ab was about $5 \mu \mathrm{m}$ in length, $1 \mu \mathrm{m}$ in width, and displayed a $\mathrm{v}^{-}$-shape completely. The strain Ac was about $10 \mu \mathrm{m}$ in length, $1 \mu \mathrm{m}$ in width, with a rod shape.

The growth of strains $\mathrm{Aa}, \mathrm{Ab}$ and $\mathrm{Ac}$ and lactic-acid forming profiles of these bacteria are presented in Fig. 1. Strain Aa showed the fastest growth and highest lactic acid formation on the BCP liquid medium. The strains $\mathrm{Ab}$ and $\mathrm{Ac}$ showed relatively slow growth and low lactic acid formation.

Three strains were isolated from the Osaka-matured sediment mud consortium. The strain $\mathrm{Oa}$ was an about $2 \mu \mathrm{m}$ cocci that was observed frequently in the chain condition. The strain $\mathrm{Ob}$ was $8-10 \mu \mathrm{m}$ in length and $2 \mu \mathrm{m}$ in width with a rod shape. Strain Oc was about $5 \mu \mathrm{m}$ in length and 1 $\mu \mathrm{m}$ in width with a rod shape.

Growth of three isolated bacteria (strains $\mathrm{Oa}, \mathrm{Ob}$, and $\mathrm{Oc}$ ) and the lactic acid formations of these bacteria are presented in Fig. 2. Strains $\mathrm{Oa}$ and $\mathrm{Ob}$ showed relatively fast growth. However, lactic acid formation by these strains was not so high when compared with that by strains $\mathrm{Aa}$ and Ac presented in Fig. 1. These growth tests were conducted under static conditions (microaerobic). For 

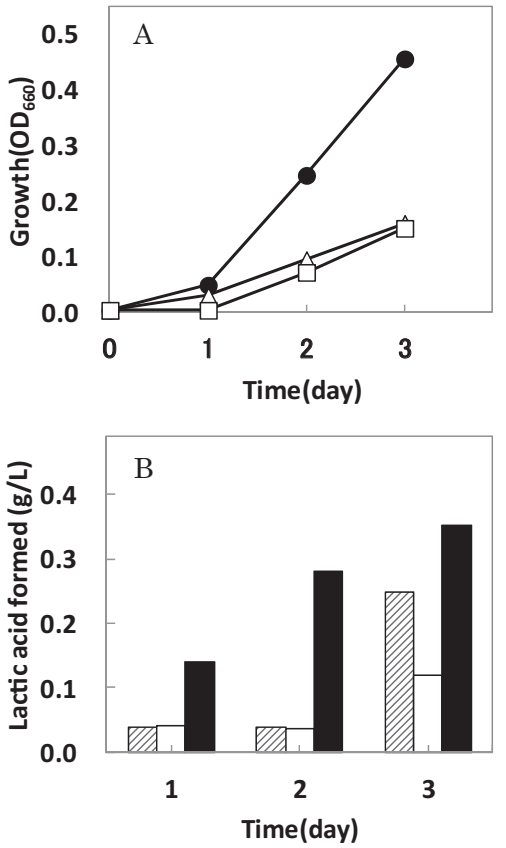

Fig. 1 Growth and lactic acid formation on BCP liquid medium by stains isolated from Ehime AI. A: , strain $A a, \square$, strain $A b, \triangle$, strain $A c$; $B$ : strain $A a, \square$, strain $A b$, Vג, strain Ac.

practical use of such bacteria for in situ purification of sediment mud on tidal flats, a complete anaerobic culture test was not preferred. High and stable growth under a static microaerobic condition was preferred.

Sediment mud purification Sediment mud purification by isolated strains is depicted in Fig. 3. Among the strains isolated from Ehime AI, strains Aa and Ac showed relatively rapid COD removal after one week (Fig. 3 A). Especially, strain Aa showed the highest COD removal after one week (initial $26.5 \mathrm{mg} / l$ to $22.7 \mathrm{mg} / l, 14 \%$ reduction). Strain $\mathrm{Ab}$ showed high COD removal after 4 weeks. Strain Ac showed low COD reduction (initial $24.4 \mathrm{mg} / \mathrm{l}$ to $22.7,6.6 \%$ reduction) after one week and no further reduced from 2-4 weeks. However, strains $\mathrm{Aa}, \mathrm{Ab}$, and Ac showed almost identical COD removal capability compared with that shown in the control experiment. The COD reduction of control experiment apparently depend on the action of bacteria, which originally survived in sediment mud on the tidal flat. Results in Fig. 3A showed that strain $\mathrm{Aa}, \mathrm{Ab}$, and $\mathrm{Ac}$
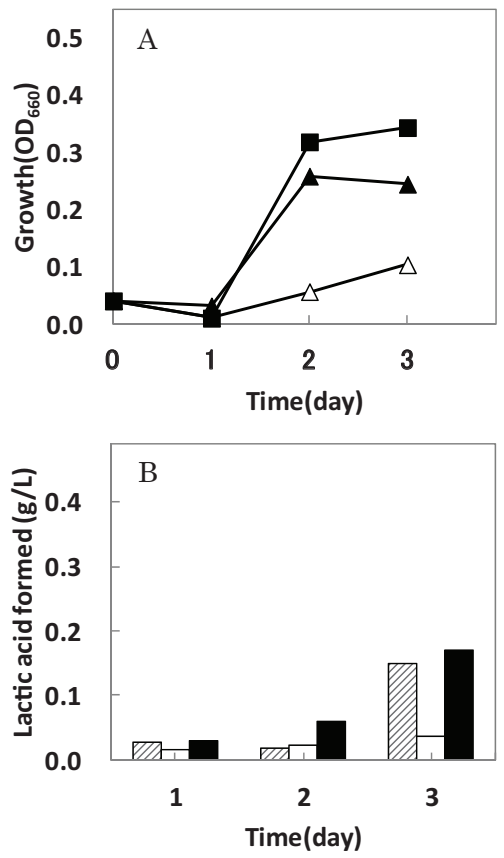

Fig. 2 Growth and lactic acid formation on BCP liquid medium by strains isolated from Osaka matured sediment mud consortium. A: $\boldsymbol{\square}$, strain $\mathrm{Oa}, \boldsymbol{\Delta}$, strain $\mathrm{Ob}, \triangle$, strain Oc; B: $\mathbf{\square}$, strain $\mathrm{Oa}, \mathbb{E}$, strain $\mathrm{Ob}, \square$, strain Oc.

apparently ineffective for COD removal of sediment mud, although strain Aa showed relatively rapid COD reduction.

Three strains from Osaka Bay showed higher performance of COD reduction (Fig. 3B) than those from the Ehime AI strains (Fig. 3A). Particularly, strains $\mathrm{Ob}$ and $\mathrm{Oc}$ showed high COD reduction after four weeks of fermentation. Strains $\mathrm{Oa}, \mathrm{Ob}$, and Oc were isolated originally from the Osaka sediment mud. These bacteria seem to be able to digest organic matter in sediment mud (mainly oily organic materials $\left.{ }^{10}\right)$. This capability also appeared during sediment mud purification from the Seno River mouth. The sediment mud compositions in Seno River mouth differed from those of Osaka sediment mud composition. However, Osaka strains showed high COD removal. These strains from Osaka are apparently potent bacteria for sediment mud purification.

Ehime AI is originally made from yogurt, natto, fermented soybean and dried yeast for making bread ${ }^{11)}$. These yogurt and natto bacteria probably have low ability to digest 


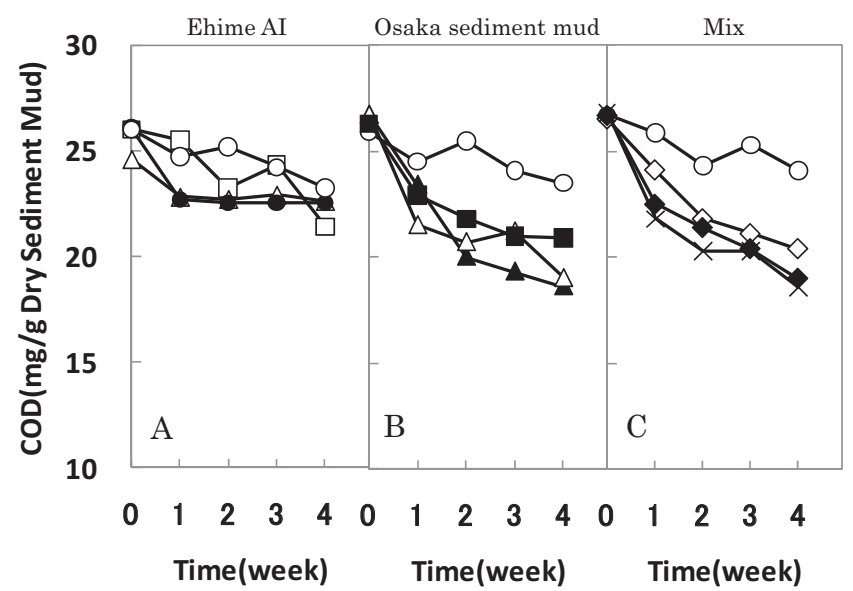

Fig. $3 \mathrm{COD}$ profiles of sediment mud during purification using isolated stains. A, Ehime Al: $\bigcirc$, control (without inoculation), $\bigcirc$, strain $A a, \square$, strain $A b, \triangle$, strain $A c$; $B$, Osaka sediment mud: $\bigcirc$, control (without inoculation), $\square$, strain Oa, $\boldsymbol{\Delta}$, strain Ob, $\triangle$, strain Oc; C, Mix: $\bigcirc$, control (without inoculation), $\diamond$, strains $A a, A b$, and $A c$ were mixed, $>$, strain $\mathrm{Oa}, \mathrm{Ob}$, and $\mathrm{Oc}$ were mixed, $\times$, strains $\mathrm{Aa}, \mathrm{Ab}, \mathrm{Ac}, \mathrm{Oa}, \mathrm{Ob}$, and Oc were mixed.

organic materials of sediment mud. Uchida and Murata ${ }^{12)}$ isolated many lactic-acid forming bacteria from marine algae on the tidal flats of Yokohama Bay. Perhaps many lactic-acid forming bacteria survive in tidal flats including in sediment mud. These lacticacid forming bacteria seem to contribute the digestion of the algae and organic matter on tidal flats ${ }^{12)}$.

With the purification of mixed bacteria (Fig. 3C), the COD reduction was almost the same as those of Osaka strains (Fig. 3B), which contributed more to the COD reduction than the Ehime AI strains. The easily cultivated lactic-acid forming bacteria are expected to be a safe and low-cost solution for sediment mud bioremediation.

For sediment mud purification, data related to the reduction of the organic matter of sediment mud are scarce. Regarding Ehime AI, no reports have described the reduction of COD of sediment mud. Miyata et al..$^{13)}$ reported that the $\mathrm{COD}$ of water inside sediment mud was reduced by half after 15 weeks with granulated blast furnace slug sprinkling at the bottom of Shimizu Bay in Shizuoka. Our results show slightly lower purification ability after four weeks, as presented in Fig. 3B. For example, COD of $26.5 \mathrm{mg} / \mathrm{g}$ sediment mud was reduced to 18.6 $\mathrm{mg} / \mathrm{g}$ sediment mud after four weeks for strain $\mathrm{Ob}$ (30.4\% COD reduction), although the experimental period was four weeks in our work. However, the possibility of reducing COD to about $50 \%$ after 15 weeks exists as described in the report by Miyake et $a l .{ }^{13)}$

Lactic acid formation during sediment mud purification Profiles of lactic acid formation in fermented sediment mud during the purification of sediment mud using lacticacid forming bacteria are portrayed in Fig. 4 . After three weeks, lactic acid formation as shown in Fig. 4A, 4B and $4 \mathrm{C}$ was active, but, it decreased after four weeks. Strain $\mathrm{Aa}$ showed high lactic acid formation throughout the four weeks (Fig. 4A). In the control experiment, lactic acid formation was less than $0.1 \mathrm{mg} / \mathrm{g}$ in dry mud. Therefore, it is not shown in Figs. 4A, 4B, and 4C. These results suggest that lactic acid formation ability is not correlated directly to COD reduction because COD reduction of sediment mud was rather higher with strains $\mathrm{Oa}, \mathrm{Ob}$ and $\mathrm{Oc}$ than with $\mathrm{Aa}, \mathrm{Ab}$ and $\mathrm{Ac}$ (Figs 3A and $3 \mathrm{~B}$ ). Strains $\mathrm{Aa}$ and Ac from Ehime AI showed high lactic acid formation in the BCP liquid medium (Fig. 1) and in sediment mud (Fig. 4A, after 3 weeks). High lactic acid forming ability of bacteria is not correlated to COD reduction of sediment mud obtained from natural tidal flat.

The total digestibility of the organic matter of the sediment mud is apparently important for COD reduction. As described above, the 


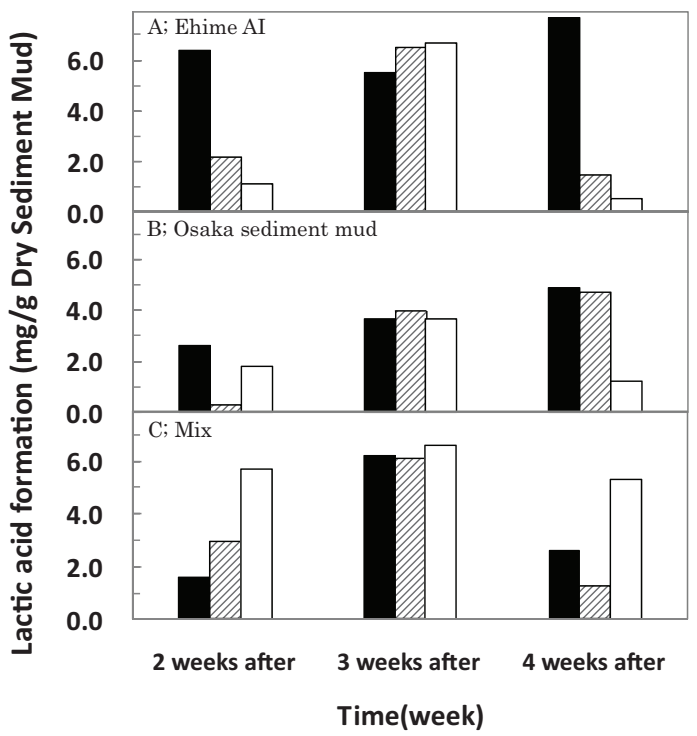

Fig. 4 Lactic acid formation profiles of sediment mud during purification using isolated strains. A, Ehime Al: $\square$, strain Aa, $\mathbb{A}$, strain Ab, $\square$, strain Ac; B, Osaka sediment mud: $\square$, strain Oa, $\mathbb{Z A}$, stain Ob, $\square$, strain Oc. C; Mix : $\square$, strains Aa, $\mathrm{Ab}$, and $\mathrm{Ac}$ were mixed, $\mathrm{Y} / \mathrm{A}$, strains $\mathrm{Oa}, \mathrm{Ob}$, and Oc were mixed, $\square$, strains $\mathrm{Aa}, \mathrm{Ab}, \mathrm{Ac}, \mathrm{Oa}, \mathrm{Ob}$, and Oc were mixed. In every control experiments, lactic acid formation was less than $0.1 \mathrm{mg} / \mathrm{g}$ sediment mud (data not shown).

organic matter (mainly oily materials) ${ }^{10)}$ in sediment mud is rather difficult for microorganisms to digest ${ }^{10,13)}$.However, lacticacid forming bacteria generally digest (decompose) high molecular weight organic matter of sediment mud to the lactic acid and lower fatty acids such as acetic, propionic and butyric $\operatorname{acids}^{10)}$. Other bacteria or microorganisms in sediment mud easily consume such low molecular organic acids and convert them to carbon dioxide and methane. The sequence of this substrate consumption seems to contribute the COD reduction. The Osaka strains have rather high digestibility of organic matter in sediment mud. The digestibility of the organic matter of such lactic-acid forming bacteria must be elucidated in greater detail.

Identification of $\mathrm{Aa}$ and $\mathrm{Ob}$ strains $\mathrm{A}$ 16S rDNA analysis revealed that strain Aa from the Ehime AI, showing the highest lactic acid formation ability, showed 100\% similarity to Lactobacucillus casei (Accession No. HM218553), a typical lactic acid bacterium used for producing fermented food and making yogurt. Strain Ob, which showed high COD reduction of sediment mud in Fig. 3B during 2-4 weeks, showed $99.8 \%$ similarity to Paenibacillus motobuensis MC10 (Accession No. AY741810). This bacterium has a safety level of one. These bacteria (starins $\mathrm{Aa}$ and $\mathrm{Ob)}$ are applicable for field use as the biologically safety bacteria in the natural field.

\section{CONCLUSIONS}

To investigate the role of lactic-acid forming bacteria for sediment mud purification, lactic-acid forming bacteria were isolated from fermented and matured sediment mud from the Osaka Bay and Ehime AI, which is an environmental preservation material. We conducted experiments to investigate the ability of these bacteria to form lactic acid and remove COD from sediment mud. Following results were obtained.

(1) Among six kinds of strains from the Osaka Bay muddy tidal flats and Ehime $\mathrm{AI}$, strain $\mathrm{Ob}$ which was identified as Paenibcacillus motobuensis showed more than $30 \%$ reduction of COD within four weeks. Other five bacteria showed 8.2$28.8 \%$ reduction of $\mathrm{COD}$ within four weeks.

(2) Among six strains isolated, strain Aa showed the highest lactic acid formation capability.

(3) High lactic acid formation ability did not always correlate with high COD reduction from sediment mud.

\section{REFERENCES}

1) Environmental Conservation Division, Hiroshima Prefecture: Annual Report of environment 1998, p218 (1998)

2 ) Environmental Division, Hiroshima City: Annual Report of environment 2009, p138 (2009)

3 ) National Institute for Environmental Studies: Studies on biogeochemical cycles and selfpurification in shallow coastal areas for preservation of marine environment, Report of Special Research from the National Institute for Environmental 
Studies, Japan, 1-49 (2000)

4 ) Asaoka, S., Yamamoto, T., and Hayakawa, S.: Removal of hydrogen sulfide using granulated coal ash, J. Japan Soc. Water Environ., 32(7), 363-368 (2009)

5 ) Ikegami, S. and Uehara, H.: Purification system with ozone and micro-bubble, Examples of Purification for Water Environment (2), 139-143 (1996)

6 ) Kimura, K.: Relationship between living things and environment on tidal flat of Tokyo Bay, Hedoro (No77), 23-32 (2001)

7 ) Iwai, S. and Uchida, C.: The present state and prospect for impovement of sediment by lime powder (3), Kankyo Gijyutu, 19(8), 522-528 (1990)

8 ) Nishino, N. and Kouchi, T.: An improvement technology of sediment and water quality by magnesium hydroxide sprinkling, Yousui to Haisui, 45(11), 1085-1084 (2003)

9 ) Ito, K., Nishijima, W., Shoto, E., and Okada, M.: Control of sulfide and ammonium release from coastal bottom sediments by converter slag, J. Japan Soc. Water Environ., 20(10), 670-673 (1997)

10) Takeno, K., Sasaki, K., Watanabe, M., Kaneyasu, T., and Nishio, N.: Removal of phosphorus from oyster farm mud sediment using a photosynthetic bacterium, Rhodobacter sphaeroides IL106, J. Bisci. Bioeng., 88(4), 410-415 (1999)

11) Ehime AI: http://www. Kihoku.ehime.jp/ guide/seikatu/

12) Uchida, M. and Murata, M.: Isolation of a lactic acid bacterium and yeast consortium from a fermented material of Ulva spp. (Chlorophyta), J. Appl. Microbiol., 97, 1297-1310 (2004)

13) Miyata, Y., Numata, N., Toyota, Y., Sato, Y., Oda, S., and Okamoto, T.: Effect of improvement of sediment using granulated blast furnace slag, Kaiyo-Kaihatu Ronbunsyu, 16(6), 345-352 (2000)

(Submitted 2011. 10. 19)

(Accepted 2012. 4. 20) 
